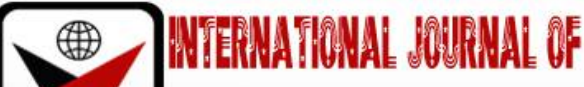

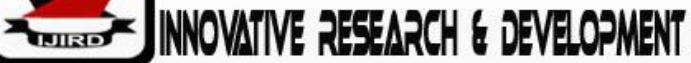

ISSN 2278 - 0211 (Online)

\section{Relevance of Visual Arts in the Promotion of IGBO Culture}

\author{
Dr. Osita, Williams Agoagbara \\ Senior Lecturer, Department of Fine and Applied Arts, Abia State University, Nigeria \\ Ejimofor, Ochiabuto \\ Senior Lecturer, Department of Architecture, Abia State University, Nigeria \\ Igolo, Iheanyichukwu \\ Lecturer, Department of Architecture, Abia State University, Nigeria
}

\begin{abstract}
:
The study considers visual arts as one of the most important phenomena in the history and development of igbo culture in terms of its preservation and promotion. It is also defined to reflect its importance to culture promotion and preservation and the entire society. Many studies have been carried out in culture related issues as well as visual arts, but no significant and comprehensive studies are made in this direction, hence the study. Primary and secondary sources of data collation as well as unstructured interviews are used to achieve the objectives of the study. Some of the findings include that ndigbo are acclaimed for the quality of their visual art works as reflected in Igboukwu Bronze Discovery of 1938, Igbo masks and masquerading and others. Igbo culture are significantly promoted and preserved through their major artifacts in local and international museums as well as those mounted at strategic locations adorning the communities. Igbo is unique and great in culture and has gained national and international recognition as conclusively noted by the study and it is followed by recommendation.
\end{abstract}

Keywords: Visual arts, Southeastern Nigeria

\section{Introduction}

Ndigbo are the people at the moment situated in the Southeastern Nigeria geopolitical zone, which comprises Abia, Anambra, Ebonyi, Enugu and Imo States. However, this geopolitical demarcation does not limit igbo to the above states only, it goes beyond south-east to the south hence there are ndigbo in Rivers and Delta states including some parts of the present Benue state of Nigeria today. The study shares the view that Ndigbo are notably farmers, traders, and educated people in the present-day Nigeria.Apart from educatedness, ndigbo are acclaimed for the quality of their works of art, drama, poetry, and other form of creative endeavours as exemplified by Igboukwu bronze discovery in 1938 by Thurstan Shaw,Uche Okeke's Projection and Promotion of Uli/ Uri linearical body and wall decorations, Chike Aniakor, Elechi Amadi, Chinua Achebe and others have significantly contributed to development of Igbo values, Culture and Civilization. Their numerous contributions have brought ndigbo international fame and recognition.

Historically, Igboukwu bronze discovery made Ndigbo, indeed Nigeria popular, including other cultural elements like mask and masquerading, exalted festivals Ekpe, Ikeji, Iwa Akwa, Oru Owerri, Iriji and others battling with extinction in contemporary times. Despite the importance of visual arts to humanity, Visual arts seems to be neglected and relegated to the background in pursuit of politics, trading, migration, suppression, fight against one another and others. Different studies have been carried out in important aspects of igbo culture without a comprehensive and significant one in this direction hence the study.

However, the study tries to situate visual arts as a body of, and a route to knowledge. It also positions visual arts as a massive source of promotion of igbo culture. It considers ndigbo as cultural and creatively endowed race in Nigeria, it also, views visual arts as a significant catalyst to the growth and development of igbo values, cultures and civilization from prehistoric times till date. Again, the study place visual arts as vanguard of cultural identity Consequently, visual arts become for ndigbo, not just arts for art sake, but a serious ritual in which the collective history and culture of ndigbo are celebrated.

Azeez (2001) is of the opinion that art as a multi-functional phenomenon closely relates to people and their cultural activities and values as it is in the southeastern Nigeria today. It serves as a social communication and commentator as well as a mediating link between the people and their culture. However, the multi-functionality of art as a field of knowledge and for expressive symbolism in a diverse and socio-cultural situation like igbo, put extra obligations on the society to explore available opportunities to grow beyond their present status in terms of culture, creativity and igbo technology. 
Art and culture are two distinct but related phenomena used to promote a people's values and identity. It must be noted that art is a significant aspect of culture. It is used to depict, project and promote culture of the people and may be massively considered when any transformative and development agenda are duely considered in the society.

Art and culture are inseparable phenomena and may not function effectively in isolation. Culture provides a suitable playground for effective existence of art, visual arts on the other hand seeks to project, document and preserve the culture. In support of this, the cultural policy of Nigeria, (1988:3) defines culture "as the totality of the way of life evolved by a people in their attempts to meet the challenges of living in their environment, which give order and meaning to their social, political, economic, aesthetic and religious norms and modes of organization, thus distinguishing a people from their neighbours."

However, it must be noted that visual arts help to complement culture as well as restore, educate, document, immortalize and promote culture in diverse ways. In view of this, therefore, the study observes that Arts and culture in Igbo society are not given their due place as they tend to be relegated to the background as any policy not directly linked to politics or looting in the contemporary Nigeria polity are not paid a due attention. These inadvertently, have impacted negatively on the entire system, hence the infiltration and adulteration of igbo culture and the entire system in Nigeria.

In 1978, according to Emeji (2001:105) experts who were assembled to draft a cultural policy for Nigeria observed that. The problem is that usually, development planning and policy making have had no conscious cultural dimensions. The emphasis usually has been on the achievement of qualitative growth. Yet the truth ought to have been obvious that the whole purpose of development planning ought to be improvement in the quality of lives of Nigerians and that such an improvement is hardly possible no matter what statistical increases in goods and services are attained. If the new changes do not consciously relate to the cultural roots and sensibilities of our people and if development is not seen consciously as an instrument for the dynamic development of Nigerians cultural heritage.

However, in his opinion, the experts suggested that Nigeria should begin systematically to use her political independence to reverse the cultural trends and to redress the imbalance in the contact awareness and encourage stable, orderly cultural change which may benefit all the geopolitical zones including ndigbo.

The study is of the view that the neglect and relegation of art and culture to the background began from the time of the colonial administrators who came and destroyed the people's artifacts and altered their culture to the extent that most of the norms and values for which ndigbo are known and respected for are discarded and regarded as fetish including religion (Africa Traditional Region) and arts particularly, Sculpture works were destroyed and regarded as fetish objects.

Oloidi (2011) states that what the European administrators, scholars and anthropologist could not understand at their time was the culturally unique, potent and conceptually fertile nature of the Nigerian traditional arts. However, some scholars, researchers may believe that the Europeans do not understand the culturally unique, creative and conceptually fertile the Nigerian traditional art were and are, to a considerable extent, this study disagrees with such views and submits that the colonial administrators were astonished and dumbfounded at such a creative and imaginative ingenuity of Nigerian traditional artists, particularly, ndigbo. They concluded, therefore, that if the Nigerian artists are not tamed, they may become world class in terms of creativity and creation of works of art. They craftly and forcefully made away with those beautiful and inspiring art works as recorded by Benin art expedition of 1897, igboukwu bronze work of 1938 in Growing (1995) and others.

The study observes that those works are scattered in USA museums, United Kingdom museum and other European countries till date. The big questions are. If these igboukwu bronze works and other igbo related culture are fetish, what are these works doing in British museums now? How much are these works worth and income they generate for Britain and other European countries on daily basis? In support of these views, Emeji (2011) states the most precious works of art created by traditional Nigerian artists were illegally and forcefully removed from many African countries. For example, the British Punitive expedition to Benin of Nigeria in 1897 marked the beginning of illegal seizure and forceful removal of priceless art works in Nigeria, indeed Africa.

This looting prompted the former secretary general of united nations educational scientific and cultural organization (UNESCO) to state as following citing Emeji (2001:104).The return of cultural assets to their countries of origin nevertheless continues to pose particular problems which cannot be solved simply by negotiated agreements and spontaneous acts--- this is a legitimate claim and UNESCO, whose constitution makes it possible for the preservation and protection of universal heritage of works of art and monuments of historic and scientific interest is actively encouraging all the needs to be done to meet it --- and these men and women have been deprived of their cultural heritage therefore, ask for their return---

The above statement is massive and significant in the history and development of visual arts and cultural heritage in southeastern Nigeria and beyond. However, it must be stated that because of monumental roles visual arts play in cultural awareness, refinement and documentation of cultural awareness, cultural heritage as well as cultural education, hence, the constant agitation and cat call for the return of these priceless artworks to the original owners. During the colonial era as noted by Neperud citing Emeji (2001:103)

The indigenous artist was in a class of specialist, a professional whose particular specialty fulfilled the artistic need of his society. The artists role and expected behaviour was then a relatively unchanging one, derived from a tradition dedicated to a refinement of artistic forms in meeting stable needs.

In view of this therefore, Emeji (2001:102) continues, citing Soyinka that those who argue that African history started with colonialism fail to comprehend that history is a process of development and that colonialism was nothing but a forceful interruption of Africa's own process of historical development. 
The study shares the view that this forceful interception and interruption of Africa's own process of historical development by the colonial administrators impacts negatively on the people's cultural policy, process and identity, for which ndigbo are grossly affected till date. For this reason, Emeji (2001:107) opines that in the declaration of the principle of international cultural cooperation adopted by the united nations General Assembly of 1966, it was resolved that each culture has a dignity and a value which must be respected and preserved, and that every people has the right and duty to develop It's culture in their rich variety and diversity". However, visual arts play complimentary role to culture in every organized society. It facilitates the effective existence of culture and culture on the other hand provides a suitable playground for massive existence of visual arts. The study shares the view that visual arts promotes culture and both work together to achieve a common goal ---- harmonious, educated and effective existence of the society.

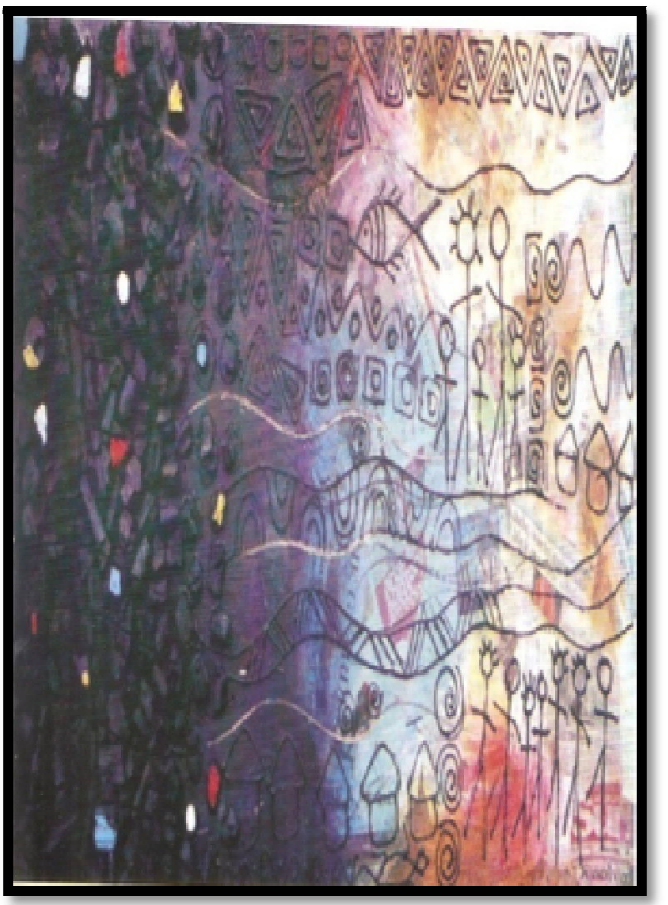

Figure 1: Uche Joel Cima, Manuscript, Mixed Media @ Osita Williams 2019

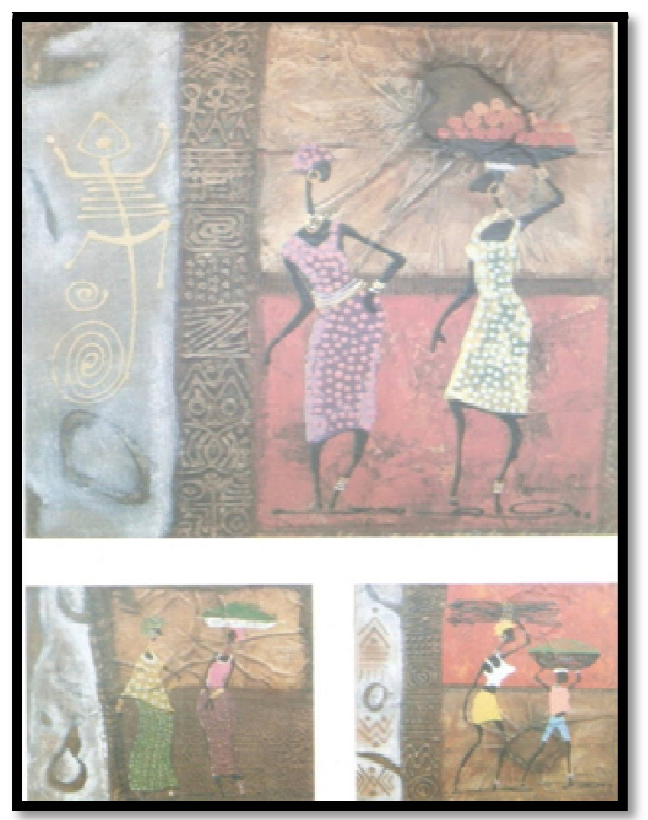

Figure 2: Ogakwu, Chinedu, as Old as Man, Variables (c) Osita Williams (2019)

\section{Visual Arts}

This is an idea, feeling, expression, information communicated by man through certain media, on two- or threedimensional platforms and may be considered a significant route to knowledge. It is connected with a person's power of reasoning and intellectual development. Visual arts as defined by Azeez (2001:41) is "a language of visual science. It is a universal language that is aesthetic but also utilitarian, imaginative, and creative." According to him, like culture art is also a way of life it is a power of doing things including skills, trade, craft or acquired expertise. Therefore, art becomes to 
ndigbo, not just a frivolous experience but also a serious ritual in which the collective history of the people (ndigbo) is celebrated. Visual arts are used as a medium of preservation, presentation, projection, and promotion of one's culture as exemplified in figures 1-5.

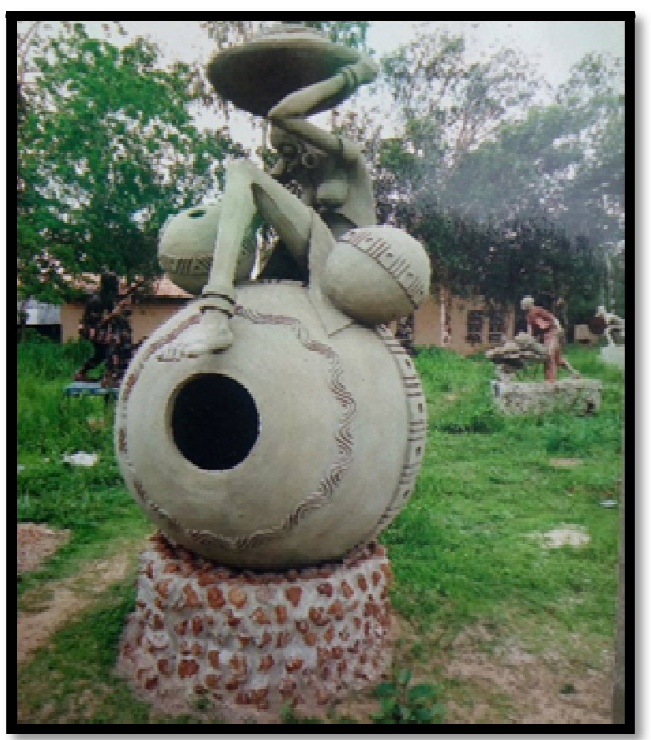

Figure 3: Okpe Byzantine (Cultural Affiliation) 2010 Direct Modelling 13ft. @ O Osita Williams 2019

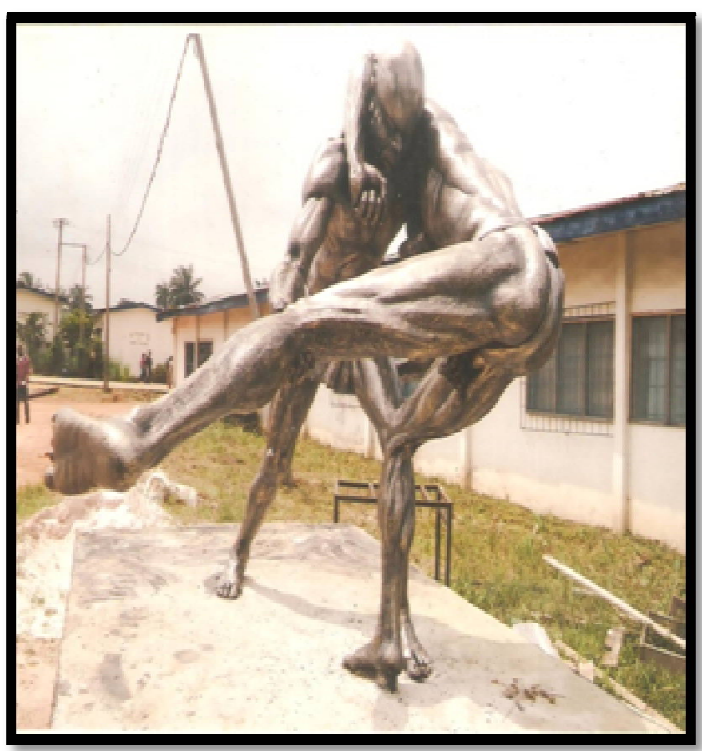

Figure 4: Maduawuke Ifesinachi J. Installation

Of Igbo Traditional Wrestling 2013 6.8 Ft @ Osita, Williams 2014

Visual arts anchors cultural economic and national development. Apart from these, visual arts are sacred and ritualistic in traditional igbo situation. During the prehistoric era, visual arts were used in adorning the shrines and representing the deities as well as symbolizing various gods like Ala, Chi, Njoku, Ikenga and others.

Visual arts in the prehistoric, colonial and post-colonial eras was an effective medium of body and wall decoration in the southeast geopolitical zone of Nigeria as exemplified in Uli/ Uri linearical art forms which later became Uli/ Uri Art movement Pioneered by Uche Okeke and made popular by Nsukka Art school in Southeastern Nigeria. However, Uli/ Uri art forms became an important phenomenon in the history and development of modern Nigeria art. Again, it represents to a greater degree igbo, culture, essence, values and igbo civilization which hitherto promote igbo cultural values and gained ndigbo international recognition till date.

\section{Conclusion}

Before the advent of colonialism, art and artist were held to a high esteem because of what they represent in the communities. However, in traditional Nigeria art era, art influences and epitomizes the people's way of life until the coming of colonialism and Christianity which have impacted negatively on igbo culture at the moment. Visual arts in southeastern Nigeria have suffered tremendous setbacks following the arrival of colonialism, Christianity and westernization which the people embraced without caution, sensibility and futuristic implications. 
Igbo culture is unique and ndigbo are imaginatively, creatively and artistically endowed and promote their high sense of creativity to project, and promote their indigenous culture and also use same avenue to preserve their culture. However, through sculpture media, painting, graphics, ceramics, textile design technology and craft, the culture of ndigbo are documented, preserved and promoted. Through this medium, people are made aware and educated about igbo civilization, values, essence, norms and others that relate effectively to the culture of ndigbo from prehistoric to modern times.

\section{Recommendations}

The study recommends, therefore, a bold and drastic as well as holistic measures to be taken by the government and concerned agencies to revamp the lost and most cultural elements of ndigbo for posterity, particularly, those battling with extinction.

Cultural centers should be built in the tertiary institutions in southeastern Nigeria to reflect the importance of culture to the society. Visual arts should be encouraged holistically in all the institutions in igbo communities. Artifacts reflecting the culture of ndigbo should be strategically mounted at public squares to reflect igbo culture, civilization and values as it is in Enugu state today, thereby adorning the cities.

Government and private individuals as well as Non-Governmental Organisations (NGO) should partner and encourage visual arts for the promotion and preservation of igbo culture. This is because art is used as a huge medium of preserving and promoting culture.

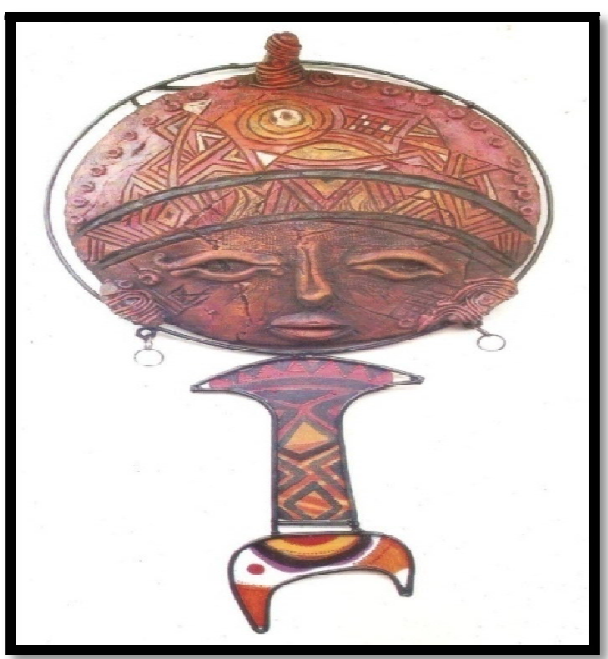

Figure 5: Chukz Okonkwo, Weaver Song,Wood And Metal $43 \mathrm{~cm}$ X 92cm (c) Ositawilliams 2019

\section{References}

i. Adam, L.S. (1996). The methodology of Arts. An Introduction, Oxford: West view press.

ii. Aniakor, C. C. (2012) "Knowledge, its production commodification and the music of violence" Africa and the politics of post coloniality, Enugu the Pan African Circle of Artist Press.

iii. Anidi, O. (2009). "As Things Fall Apart and in Place: Visual Interrogation" 1st Festival on Igbo Civilization, Art Exhibition Catalogue, Enugu: CIDJAP.

iv. Ayakoroma, B.F. (2011) Arts, Culture, Language and National integration Abuja: National Institute for cultural orientation.

v. Azeez, A. (2001). "Art/ Culture and the politics of Identity in Africa" a Discursive Bazaar, Enugu: The Pan-African circle of Artists Publishers.

vi. Chima, G.N (2018) "Water, water everywhere but not enough" 37th Inaugural Lecture, Aba; Abia State University press.

vii. Cultural policy of Nigeria (1988). Lagos: Federal Government Printing Press

viii. Ekpo, E. (2008). From Shrine to Showcase Masterpiece of Nigerian Art, Abuja: The Ministry of Information and Communication Press.

ix. Emeji, M. J. (2001). "in search of Community Arts Policy and Animation in Africa: Agenda for GrassrootArts and Resource Development" A Discursive Bazaar: writing on African art, culture, enugu: The Pan-african circle of artists publishers.

x. Gowin, L. (1995) A History of Arts, Oxford: Barres and Noble Inc.

xi. Hornby, A.S. (1995) Advanced Learners Dictionary of Current English, 5thed. Oxford: Oxford University press.

xii. Ikwuegbu, F.N (2010) "Creativity and imagination" sine qua Non for sustainable National Development". Journal of Nigerian Languages and Cultures, Vol 12, No 1, Enugu: San press Ltd.

xiii. Ikwuemesi, K. et al (2009). 1 $1^{\text {st }}$ Festival on Igbo Civilization, Art Exhibition Catalogue, Enugu: CIDJAP.

xiv. Mish (2008) Merrian- Websters collegiate Dictionary,11 thed.Springfield, massachusetts." Marrian Webster Inc.

xv. Ogakwu, C., Odoh, N. (2012). Africa and the Politics of Postcoloniality, Enugu: The Pan-African Circle of artist Publisher. 
xvi. Ojewuyi, O. (2011) Katanfuru: The illogic of Culture-Nomics in Nigeria Cultural Administration, Abuja: National Institute for Cultural orientation.

xvii. Oloidi, O. (2011). The Rejected stone: Visual Arts in an Artistically Uninformed Nigerian Society. 58th Inuagural Lecture Nsukka: University of Nigeria Senate Ceremonial Committee.

xviii. Osita, W.A. (2015) "Sculpture Garden Experience As Total therapy” Journal of Visual Dialects vol. 1, NO 1.Abraka: Egosay Nigeria Ltd.

xix. Preble and Preble (1994) Art Forms: An Introduction to the Visual Arts, 5th ed.New York: Harper Collins college publishers.

xx. Agoh, F. M. (1999) 74 Yrs, Retired Civil Servant Interviewed at Lagos Nigeira.

xxi. Agomoh, C. (2017), 73Yrs, Retired Civil Servants (Principal), interviewed at Umunemeze Afugiri, village, Umuahia North L.G.A Abia state.

xxii. Ekechukwu, M. C. (2018). 82 Yrs, Retired Civil servant, Interviewed at Umunemeze Afugiri village, Umuahia North L.G.A, Abia State.

xxiii. Emuchay Christian (2019), 65 Yrs, retired civil servant, interviewed at Azumiri, Ndoki, Ukwa East, L.G.A Abia state.

xxiv. Ezeagha, A. (2019) 61 Yrs, Retired Civil Servant, Interviewed at Federal low cost Housing, Okigwe, Imo state.

xxv. HRH, Eze Ngwuli Charles (2018), 63 Yrs, retired civil servant, interviewed at his royal palace, Umuegwu Afugiri, Umuahia North L.G.A, Abia State.

xxvi. Udeagha Emenike (2018) Interviewed at Ikenegbu Housing Estate Owerri, Imo State 13 ${ }^{\text {th }}$ of May 2018, June 10.42 Am, Age, 51 years occupation-Sculptor (UNN). 